\title{
Time Management and Academic Performance of Postgraduate Students in Nigerian Universities
}

\author{
${ }^{1}$ Nzewi, Hope Ngozi (Ph.D), \\ email:dr_mrs_nzewi@yahoo.com \\ ${ }^{2}$ Chiekezie,Obianuju Mary(Ph.D), \\ email:chiekezie@yahoo.com \\ ${ }^{3}$ Ikon, Michael A.(Ph.D), \\ Email:hicenco@yahoo.com \\ ${ }^{1-3}$ Department of Business Administration, \\ Nnamdi Azikiwe University, Awka
}

\begin{abstract}
This study assessed time management and academic performance of postgraduate students in Nigerian Universities. The specific objective of the study is to determine whether time management is the only variable that affects the Cumulative Grade Point Average of postgraduate students in selected Universities in Nigeria. Survey research design was employed and data were analyzed using mean and standard deviation. Z-test statistics was used to test the formulated hypothesis at $5 \%$ level of significance. Our finding revealed that time management is not the only factor that affects the Cumulative Grade Point Average of postgraduate students in selected Universities in Nigeria. In addition, family workload and other psychological factors influence the academic performance of postgraduate students in Nigerian Universities. We therefore, recommend that postgraduate students should undergo physical, medical, psychological and cognitive tests before they are certified fit to take any postgraduate examination. Effective time management skills should be taught to the postgraduate students.
\end{abstract}

Key words: Time management, Academic Performance, Postgraduate Students, Cumulative Grade Point Average and Nigerian Universities.

\section{Introduction}

Time is a priceless resource and continues to pass by without coming back. There are many things we dream to do and have to do in the midst of competitive conditions in business life. For those who cannot 
perform the necessities of time management effectively in their private and business lives will result in failure and unhappiness (Mercanlioglu, 2010 \& Shellenbarger, 2009). According to Drucker, quoted in Repak (2007), time is the scarcest resource available and many times our highest priorities are not reflected in our actual daily activities. Graduate students face a number of pressures that are distinct from the stresses that undergraduates face. Given their non-residence in universities, academic pressures, family and financial obligations, the need for proper planning and time management to avoid distress becomes imperative (Patton, 2012). Cemaloglu \& Sevil (2010), posit that there is a significant and positive relation between time planning and academic achievement of students. This finding corroborates the prior study of Eilam \& Aharon (2003), Davis (2000) and Green \& Skinner (2005). The problems of graduate students in Nigerian Universities include time management, study habits, note taking, internet skill, the elimination of distraction and assigning a high priority to study (Igun \& Adogbeji 2007).

\section{Statement of the Problem}

Postgraduate students in Nigerian Universities appear entangled in how best to manage time resource effectively and efficiently in both their academic pursuits and workloads in order to ensure performances in various fields of endeavour. Statistics from the Global Competitiveness Index (2011-2012), indicate that Nigeria ranks 114 (3.18\%score) out of 139 countries surveyed in provision and quality of higher education and training in the world. The ranking web statistics of Universities (2012) in the world show that the highest ranked university in Nigeria, University of Ibadan, occupies 3215 position (world rank), 6996 position (presence rank), 3813 position (impact rank) 8345 position (openness rank) and 1318 position (excellence rank). Given the competing myriads of responsibilities of graduate students (Patton, 2012), the question is: could time management among the postgraduate students in Nigerian Universities be the only factor that affects their academic performance? 


\section{Objective of the Study:}

The primary objective of the study is to assess the relationship between time management and academic performance of the postgraduate students in Nigerian Universities. The specific objective is to determine whether time management is the only variable that affects the Cumulative Grade Point Average (FCGPA) of postgraduate students in Nigerian Universities.

\section{Statement of the Hypothesis}

The hypotheses of this study are:

$\mathrm{H}_{0}$ : Time management is not the only variable that affects the Cumulative Grade Point Average of postgraduate students in Nigerian Universities.

$\mathrm{H}_{1}$ : Time management is the only variable that affects the Cumulative Grade Point Average of postgraduate students in Nigerian Universities.

\section{Review of Relevant Literature}

Prior studies on time management among Postgraduate students present varied perspectives and findings (Repak, 2007; Cemaloglu \& Sevil, 2010; Elian \& Aharon, 2003). In their study, Claesson, Eerde, Rutte \& Roe (2007), reviewed 32 empirical studies on time management conducted between 1982 and 2004 in order to provide an overview of the current state of the art in time management research. The review reveals that time management behaviour relate positively to perceived control of time, job satisfaction and health, while it is negative to stress. However, the relationship with work and academic performance is not clear.

Igdem (2010) investigated the relationship of time management to academic performance of Master level students. Employing survey research design, his findings show that there is a significant positive relationship between time management and academic performance of Master's level students. He concluded that the competitive conditions in business life have forced people and business to do so many things simultaneously. 
In a related study, Davis (2000) examined the effect of time management on work and academic settings. Using survey research design, his results suggest a positive relationship between time management and work academic settings and increased performance. A number of experts (Wright, 2002, Ancona, Goodman, Lawrence \& Tushtman, 2001, Gorge \& Jonas, 2000), assessed the need to incorporate time in theoretical models and research designs in organizations. Applying survey method, their findings indicate that time management facilitates improvement in effort.

Cognizance of the non-acceptability of a universal definition of time management, Shellaenbarger (2009) views time management as behavioral change techniques that help people get organized, clarify thinking and increase output. Eilam and Aharon (2003) believe that time management is a way of monitoring and controlling time. However, Claessons, Eerde, Rulte \& Roe (2007) observed that time cannot be managed because it is an inaccessible factor. The only way a person deals with time is by influencing behavioral attitude.

\section{Measurement of academic performance}

Measurement of public sector performance, especially in provision of service in Universities is a complex issue. It involves comparing public resources in terms of total amount of money expended, the personnel and other resource with outputs such as students' academic performance, graduation rate and quality of research (Abdulkareen \& Oyeniran, 2011). Universities are established to produce skilled manpower and good performance in higher education is expected to bring positive growth (Blanchard, 2004).

Coelli, Prasada and Battesse (2000) state that the output measures of Universities in terms of teaching include the following:

Number of students admitted

Number of full-time equivalent students

Number of students in different disciplines

Number of undergraduates and postgraduate students

Number of weighted full-time equivalent students 
In the perspective of Ana \& Edgar (2002), the output measures include:

* Number of recipients of Bachelor, Master and Doctoral Degree granted by the university.

Teaching load of the department which is an index computed by the university administration, taking into account the number of hours taught by the department on graduates and undergraduate programmes plus hours for supervising students' projects.

Undergraduates/graduates work volume, sum of number of students enrolled on a course multiplied by the number of credit hours of the course for all courses.

\section{Cumulative Grade Point Average (CGPA)/Grade Point Average}

The academic performance of a student in any semester is measured with the grade point average (G.P.A). Cumulative Grade Point Average is the measure of the students overall academic performance at any given point in his programme. (GPA is an up-to-date weighted mean of the grade points, where the weights are the course credit units (Nnamdi Azikiwe University Academic Programme, 2010).

However, Young (2005) critiqued CGPA as inadequate measure of academic performance and suggested in his studies that Item Response Theory (IRT) based GPA is a more reliable measure of performance which is used to measure the validity of traditional preadmission's information.

\section{Theoretical framework}

This study is anchored on the pickle jar theory which is the latest theory of time management taught in leadership course. Jeremy Wright developed the theory after his series of studies (Olubor \& Osunde, 2007). The pickle jar theory states that activities and responsibilities of people need be balanced using effective time management system. Time is approximately allocated for everything and things fit well where they are expected to fit. This theory is predicated on the fact that individuals have many large priorities in lives such as studies, workload, leisure, family responsibilities, sleep and rest. According to the theory none of these tasks is bad, but what is important is efficient management in the 
midst of time constraints in order to enhance performance in various areas of life.

Pickle theory as it relates to time management and academic performance of postgraduate students in Nigerian Universities, emphasizes the need to identify one's large priorities during the day (lecture attendance, workload, seminar presentation, proposal presentation, consultation of library materials, family responsibilities, project/thesis/ dissertation defence so as to ensure higher cumulative grade point average, which is an index of academic performance in Nigerian Universities).

\section{Methodology}

Survey research design was used in this study in order to collect information. Questionnaire instrument was administered on the sampled respondents. The population of this study is infinite sequel to the fact that it cannot be easily ascertained. We adopted cluster and stratified sampling techniques, which are categories of probability sampling technique. This technique ensured that all the elements of the population had equal chances of being selected. We focused on postgraduate students in selected universities from the six geopolitical zones of Nigeria. Owing to the infinite nature of the population, a statistical formula for determining sample size from unknown universe was employed (Okeke, Olise \& Eze, 2008). This study assumed 5\% level of significance $(\alpha)$ (See appendix 1). 
Table 1:1 Categories of Respondents Sampled

\begin{tabular}{|l|l|l|l|}
\hline S/N0 & $\begin{array}{l}\text { University class category } \\
\text { (PGD, MBA, M.Sc, } \\
\text { Ph.D) \& senior lecturers }\end{array}$ & $\begin{array}{l}\text { Geopolitical } \\
\text { Zone/state }\end{array}$ & $\begin{array}{l}\text { Number of } \\
\text { respondents }\end{array}$ \\
\hline 1 & $\begin{array}{l}\text { Nnamdi Azikiwe } \\
\text { University, Awka }\end{array}$ & $\begin{array}{l}\text { South } \\
\text { east/Anambra }\end{array}$ & 86 \\
\hline 2 & $\begin{array}{l}\text { University of } \\
\text { Portharcourt }\end{array}$ & $\begin{array}{l}\text { South } \\
\text { south/Rivers }\end{array}$ & 53 \\
\hline 3 & University of Lagos & $\begin{array}{l}\text { South } \\
\text { west/Lagos }\end{array}$ & 41 \\
\hline 4 & $\begin{array}{l}\text { Abubakar Tafawa balewa } \\
\text { University, Bauchi }\end{array}$ & $\begin{array}{l}\text { Northeast/Bau } \\
\text { chi }\end{array}$ & 23 \\
\hline 5 & $\begin{array}{l}\text { Ahmadu Bello } \\
\text { University, Zaria }\end{array}$ & $\begin{array}{l}\text { Northwest/Ka } \\
\text { duna }\end{array}$ & 18 \\
\hline 6 & $\begin{array}{l}\text { University of Markurdi, } \\
\text { Gboko }\end{array}$ & $\begin{array}{l}\text { Northcentral } \\
\text { Benue }\end{array}$ & 25 \\
\hline & \multicolumn{2}{|l}{} \\
\hline
\end{tabular}

\section{Source: Field Survey Data, $5^{\text {th }}$ May-30 ${ }^{\text {th }}$ July, 2012}

Data were collected from primary and secondary sources. The primary data were gathered from the respondents to elicit, opinions, attitudes and preferences concerning the effect of time management on the Cumulative Grade Point Average of post graduate students in Nigerian Universities. Questionnaire method was employed because it provides an efficient way of gathering responses from a large population (Osuala, 2001). Arguably, questionnaire is the most used method for data collection (Ezejelue, Ogwo \& Nkamnebe, 2008). Structured questions were posed to obtain answers from respondents. Textbooks, journal and internet materials constituted the secondary sources. Out of the 246 copies of questionnaire distributed, 197 copies were retrieved (80\%) and 49 copies $(20 \%)$ were missing during the period of distribution and collation by the authors and research assistants.

Content validity and construct validity were used to validate the structured questionnaire instrument by administering 20 percent of 
copies of the questionnaire to experts in management studies. Content validity explains the extent of coverage of the research topic, while constructs validity, defines the capacity of the instrument to measure variables.

\section{Data Analysis}

The mean and standard deviation were utilized to analyze the data. We employed a modified 4-point likert scale and the response options and weight allocated were strongly Agree (1 point), Agree (2 points), Disagree (3 points) and Strongly Disagree (4 points). The analysis was made based on the data in table 1.2

\section{Hypothesis Testing}

$\mathrm{H}_{0}$ : Time management is not the only variable that affects the cumulative Grade Point Average of postgraduate students in Nigerian Universities.

The hypothesis of this study was tested with the data in table 1.2 . Z-test statistical tool was used to empirically test the hypothesis that guided the study.

Mean of Population $(\mu): \frac{4 \times 197 \times 9}{9}=\frac{7092}{9}=788$

Mean of Sample (x): $\sum \quad \frac{5634}{\text { \ }} \quad=626$

Standard deviation $(\delta): \frac{\sqrt{ } \frac{\sum(\mathrm{x}-\ddot{\mathrm{x}})^{2}}{\mathrm{n}}=}{\sqrt{111,082}}=\sqrt{12,342}$

Standard deviation $(\delta):=110$

Z-test statistics: $\frac{\ddot{x}-\mu}{O}=\frac{626-788}{48}=\frac{-162}{110}=-1.47$

Decision: since Z-test calculated $=-1.47<1.96(\mathrm{Z}$ table value) at $5 \%$ level of significance, we accept the null hypothesis, which states that 
time management is not the only variable that affects the Cumulative Grade Point Average of postgraduate students in Nigerian Universities. Therefore the alternate hypothesis is rejected.

\section{Analyses of Findings and Policy Implications}

The first finding from the hypothesis testing reveals that time management is not the only variable that affects the Cumulative Grade Point Average of postgraduate students in Nigerian Universities. This is corroborated by the earlier study of Igun \& Adogbeji (2007) which shows that the problems of postgraduates students in Nigerian Universities include time management, study habits, note taking, internet skill, distractions and assigning a high priority to study. This finding is also in line with Patton (2012), who posited that the nonresidence of many postgraduate students. academic pressure, family and financial obligations have affected their academic performance. The policy implication is that the existing policies on admission and registration of postgraduate students should be reviewed by the various Management, Senate and Governing councils of Nigerian Universities in order to monitor the adherence of postgraduate students to academic regulations. Most probably, if the Cumulative Grade Point Average is not improved upon, the Global Competiveness Index and World ranking of universities would continue to jeopardize the position of Nigeria.

Finding from questionnaire response indicates that family and workload responsibilities are not the only factors that influence the Cumulative Grade Point Average of Nigerian Postgraduate students. This agrees with the position of Claessons, Eerde, Rulte \& Roe (2007) that time cannot be managed because it is an inaccessible factor. The implication of this findings is predicated on the possibility that health, biological and other psychological variables could affect the Cumulative Grade Point Average of postgraduate students in Nigerian Universities especially during examination period.

\section{Conclusion and recommendations}

It is evident from this study that time management is not the only variable that affects the Cumulative Grade Point Average of postgraduate students in Nigerian Universities. Additionally, other 
intervening factors such as health, biological, psychological and nonresidency of many postgraduates students are greater forces that could affect the academic performance and in corollary, the Cumulative Grade Point Average of the focused students.

In the circumstance therefore, this study advocates that for any improved and sustained academic performance of postgraduate students in Nigerian Universities, the students should undergo physical, medical, psychological and cognitive readiness test before they are certified fit to take any postgraduate examinations. Besides, the curriculum of the working postgraduate students should be revised so as reduce the credit load and extend the duration of the programme for many years, such as 4-academic sessions for master's students on part-time and 6-academic sessions for Ph.D students. Effective time management skills should be taught to the postgraduates students. It is our hope that these recommendations would serve as strategies and options for socioeconomic development of Nigeria and Africa in general.

\section{References}

Abdulkareem, A.Y. \$ Oyeniran, S (2011). "Managing the performance of Nigerian Universities for sustainable development using data envelopment analysis." Internet Journal of Academic Research in Business and Social Science. 1 Special Issue.

Ana, L.M.L \& Edgar, A.L. (2002). Data envelopment analysis (DEA) and fuzzy set to assess the performance of academic department: A case study of Federal University of Santa Catarina. Pesquisa Operational. 22(2), 217-230. Dio:10.159/so1D1743822002000200008

Ancona, D.G, Goodman, P.S Lawrence, B.S.\$ Tushman, M.L.(2001). "Time in review". 26 PP 645-663.

Blanchard, O. (2004). "Economics future of Europe". NBER Working Paper 103(10) 
Cemaloglu, N.\$ Sevil, F (2010). “The relation between time management skills and Academic achievement of Potential Teachers". Educational Research Quarterly, 33 (4)pp 3-23

Claessens, B.J.C, Eerde, W.V, Rutte C.G.\$ Roe, R.A. (2007). “A Review of the Time Management Literature" Available online at http://www.arno.unmaas.n retrieved on $28^{\text {th }} \mathrm{July}$, 2012

Coelli, Prasada, R.T.D \& Battesse, G.E. (2000). An introduction to efficiency and productivity analysis. United State of America: Springer International Series.

Davis, M.A (2000). :Time and the nursing home assistant relations among time management, perceived control over time and work-related outcomes. "A Paper presented at the Academy of Management, Toronto

Drucker, P in Repak, N. (2007)." Time Management Available online at www.gradresources .org.Retrieved on $19^{\text {th }}$ August, 2012

Eilam, B.\$ Aharon, I. (2003). "Students planning in the process of selfregulated learning". Contemporary Educational Psychology, 28,pp 304-334

Ezejelue, A.C, Ogwo, E.O \& Nkamnebe, A.D. (2008). Basic principles in managing Research project, Aba: Afritowers Limited.

George, J.M \$ Jonas, G.R (2000), "The role of time in theory and theory building. "Journal of Management 26(4) pp.

Green, P.\& Skinner, D. (2005). "Does time management training work: an evaluation. "International Journal of Training and Development .9. Pp124-139. 
Igdem, M. (2010), “The Relationship of Time Management to academic performance of masters level students". International Journal of Business and Management Studies 2 (1)657684.

Igun, S.E.\$ Adogbeji, O.B.(2007). "Study habits of postgraduates students in selected Nigerian Universities" Library Philosophy and Practice (e-Journal). Paper 153 Available online at http://digtalcommons.unl.eduRetrieveon 11thJuly, 2012.

Mercanlioglu, I (2010). "The relations of time management to academic performance of master level students." International Journal of Business and Management Studies. 2(1)

Nnamdi Azikiwe University Academic Programme (2000). Department of Electrical Engineering, Available online at http://unizik.edu.ng/dep.tmnts/index.php?rx8 tion $=9858111 \#$ Retrieved on $10^{\text {th }}$ July,2012

Okeke, T.C, Olise, M.C \& Eze, G.A. (2008). "Research methods in business and management sciences. Enugu Iyke Ventures Production.

Olubor, R.O. \& Osunde, U.A (2001). “Analysis of personal study time and leisure among University Undergraduates in Southern Nigeria." Available online at http://www.freepateronline.com. Retrieved on $15^{\text {th }}$ July, 2012

Osuala, E.C.(2001). Introduction to research methodology. Onitsha Africana Fep Publishers.

Patton,S. (2012)." College Struggle to Respond to Graduates Students in Distress". Available online at http://www.gradresources.org Retrieved on $21^{\text {st }}$ August, 2012 
Ranking Web of Universities (2012). Available online at http"//www.webometrics.infoRetrieved on $2^{\text {nd }}$ September, 2012.

Shellenbarger, S. (2009). "Testing time management strategies". The Wall Street Journal, Work and Family. Available online at wsj.com/article. Retrieved on July 27, 2012.

World Economic Forum (2011), “The Global Competitiveness Report 2011-2012

Wright, T.A (2002). "Dialogue: the importance of time in organizational research. "Academy of Management Journal. 45.pp 725-741.

Young, J.W. (2005). "Adjusting the cumulative GPA using item response theory". Journal of Educational Measurement. 27(2) 175-186 Available online at http://onlinelibrary.wiley.com Retrieved on $13^{\text {th }}$ July, 2012 